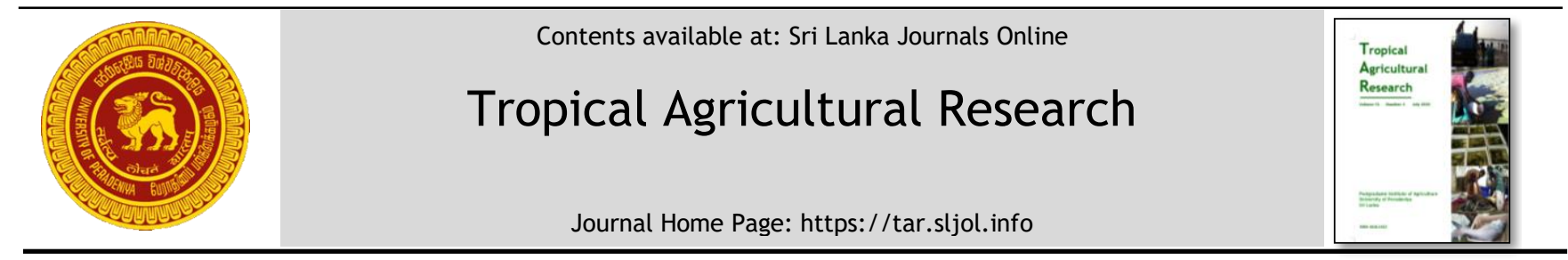

\title{
Development of French Bread Using Flour Formulations with Wheat, Rice and Locally Available Legumes, and Evaluation of its Sensory and Nutritional Properties
}

\author{
P.P.G.S.P. Bandara ${ }^{1}$ and P.C. Arampath ${ }^{2 *}$ \\ ${ }_{1}^{1}$ Postgraduate Institute of Agriculture, University of Peradeniya, Peradeniya, Sri Lanka \\ ${ }^{2}$ Department of Food Science \& Technology, Faculty of Agriculture, University of Peradeniya, Peradeniya, Sri Lanka.
}

\section{ARTICLE INFO}

\section{Article history:}

Received: 15 August 2019

Accepted: 03 November 2019

Revised version received: 19 June 2020

Available online: 1 July 2020

\section{Keywords:}

Bakery products

Crust colour

Crumb structure

Mung bean

Sensory attributes

\section{Citation:}

Bandara, P.P.G.S.P. and Arampath, P.C. (2020). Development of French Bread Using Flour Formulations with Wheat, Rice and Locally Available Legumes, and Evaluation of its Sensory and Nutritional Properties. Tropical Agricultural Research, 31(3): 25-36.

DOI: http://doi.org/10.4038/tar.v31i3.8394

Bandara, P.P.G.S.P.

https://orcid.org/0000-0003-4471-9343

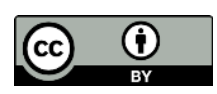

\section{ABSTRACT}

French bread made using different ratios of wheat, soya bean, chickpea and brown rice were evaluated for the sensory properties and nutritional profile, compared with French bread made of wheat flour. Two composite flour mixtures, $30 \%$ (10\% soya bean flour, $10 \%$ brown rice flour, $10 \%$ chickpea flour) and $40 \%$ (10\% soya bean flour, $10 \%$ brown rice flour, $20 \%$ chickpea flour) showed their suitability as compatible composite flour mixtures for French bread making without affecting the sensory attributes, namely, crust colour, aroma, taste, texture and overall acceptability. The French bread prepared using 40\% composite flour showed significantly higher $(\mathrm{P}<0.05)$ contents of protein $(14.80 \pm 0.02 \%)$, fat $(5.39 \pm 0.01 \%)$, fibre $(1.57 \pm 0.04 \%)$ and ash $(2.09 \pm 0.01 \%)$ than French bread prepared using $30 \%$ composite flour which contained protein at $14.03 \pm 0.01 \%$, fat at $4.99 \pm 0.06 \%$, fibre at $1.35 \pm 0.01 \%$ and ash at $1.85 \pm 0.02 \%$, and these parameters were significantly higher than the same parameters in French bread prepared using $100 \%$ wheat flour. The moisture $(30.33 \pm 0.13 \%)$ and carbohydrate $(47.45$ $\%$ ) contents of $30 \%$ composite flour substituted French bread was significantly higher $(\mathrm{P}<0.05)$ than those in $40 \%$ composite flour substituted French bread (Moisture 29\%, carbohydrates $47 \%$ ). Percentage increase of the constituents of French bread with $30 \%$ and $40 \%$ composite flour formulations were protein by $9.1 \%$ and $14.9 \%$, fat by $105.3 \%$ and $121.8 \%$, fibre by $55 \%$ and $80.45 \%$ and ash by $31.2 \%$ and $48.23 \%$, respectively. The study concluded that utilization of composite flour of locally available cereals and legumes instead of $100 \%$ wheat flour in French bread making contributes to improve the nutritional profile and benefits the local bakery industry.

\footnotetext{
*Corresponding author : pcarampath@gmail.com, pca@pdn.ac.lk
} 


\section{INTRODUCTION}

Modern day consumers prefer food products with health benefits, which are rich in nutrients, with desirable sensory attributes in addition to convenience. Prevalence of noncommunicable diseases such as diabetes, cardiovascular diseases, obesity, cancer and chronic kidney diseases has gained much attention of consumers, producers and regulatory authorities, causing concerns on many commonly consumed foods (Bibiana et al., 2014; Bhatt and Gupta, 2015).

Bread is a popular, convenient food product consumed across the globe by all age groups. It is a leavened food, produced using wheat flour, yeast, water, sugar, fat, salt and other ingredients. Mixing of ingredients, kneading, proofing, shaping, and baking are done in sequence in making bread (Wickramarathna and Arampath, 2003; Dewettinck et al., 2008). 'French bread' or 'French baguette' is a specialty bread, which is considered as a symbol of French culture. French bread is commonly distinguishable by its traditional 'wand' shape with approximate length of 65 $\mathrm{cm}$ and diameter of $5-6 \mathrm{~cm}$, the crust, which is beautiful, crispy and golden brown in colour, and the interior which is light and chewy (Baardseth et al., 2000: Tweed, 1983). The main ingredients are wheat flour, water, yeast, salt and egg white. Although French bread is higher in price, consumer demand and popularity is on the increase. However, the consumption of bread and speciality breads such as French bread is also associated with health issues such as gluten intolerance and contribution for diabetes.

Wheat (Triticum aestivum) flour is the main flour used in making most types of bread and other bakery products (Comino et al., 2013). Gluten is a complex mixture of two distinct proteins, glutenins and gliadins present in wheat flour. Further, gluten is a family of storage proteins known as prolamins that are naturally found in certain cereal grains, such as wheat, barley, and rye. In bread making, gluten is responsible for the unique viscoelastic and adhesive properties in the dough, contributing to sponginess and elasticity in baked products (Shewry et al.,
2002). Due to these unique properties of gluten in wheat flour, a wide range of diversified bakery products with desirable sensory attributes are produced worldwide (Færgestad et al., 2000). Protein content in wheat $(14.4 \%)$ is relatively high compared to other major cereals (Devi, et al., 2014). However, wheat flour is believed to be associated with problems such as obesity, high Glycaemic Index (GI) and a range of adverse reactions including allergies, coeliac disease and non-coeliac gluten sensitivity (Bibiana et al., 2014; Shewry and Hey, 2016).

Although rice is the staple food in Sri Lanka, bread consumption is substantially higher among the urban population due to the convenience provided for the busy lifestyle, free availability, and ready-to-eat nature. Wheat is not locally grown since the soil and climatic conditions are not favourable for its cultivation, and therefore, the local demand for wheat flour is totally fulfilled by importation.

In order to overcome the nutritional issues in wheat, formulation of bread can be considered as a promising alternative (Bhatt and Gupta, 2015). Cereals and legumes are rich sources of carbohydrate, protein, dietary fibre, vitamins and minerals which are important for human health. Legumes are the best plant source for providing proteins. Chickpea (Cicer arietinum) is a legume rich in fibre, protein, manganese and iron which has a low GI. Soya bean flour contains a higher amount of protein (38$40 \%$ ), fat (18-20\%), amino acids (lysine 5-6\%) and other bioactive compounds such as isoflavones (Sabanis and Tzia, 2009). Cereals such as rice contain significantly higher amount of fibre and mineral than in wheat. Flour of cereal and legumes is widely used in bakery, confectionary and savoury products (Bibiana et al., 2014; Dooshima, 2014).

Partial substitution of wheat flour with other alternative flour types such as malted and fermented sorghum (Hugo et al., 2000), Okra (Wickramarathna and Arampath, 2003), rice flour (Noomhorm, et al., 1994; Kadan, et al., 2001), composite flour mixtures (wheat, banana and soya beans)(Olaoye et al., 2006), banana flour (Mepba et al., 2007), cassava (Eddy et al., 2007), germinated and non- 
germinated soy bean flour (Rosales-Juárez, et al., 2008) have been reported in bread making. The locally available cereals and legumes, which are rich in nutrients, are available in abundance during their harvesting seasons, which is inadequately used in value addition. Further, the partial substitution of wheat flour with locally available flour types (cereals and legumes) in French bread making has not been investigated before.

Therefore, the objective of this research was to develop a composite flour mixture consisting of soya bean, mung bean, chickpea and brown rice for partial substitution of wheat flour and thereby to improve the nutritional profile and sensory attributes of the French bread.

\section{MATERIALS AND METHODS}

\section{Raw materials}

The raw materials, wheat flour, soya bean, chick pea, brown rice, mung bean, margarine and instant yeast were purchased from a local supermarket. Margarine was stored in the refrigerator and other ingredients at ambient temperature $\left(27 \pm 2{ }^{\circ} \mathrm{C}\right)$ until used.

\section{Preparation of flour}

Soya bean, chickpea, brown rice and mung bean were cleaned removing physical contaminants, washed, oven dried and ground using an electrical grinder (Wipro ${ }^{\circledR}$ ) and sieved (ASTM E11:87, mesh No 50) to obtain a uniform particle size $(300 \mu \mathrm{m})$.

\section{Formulation of composite flour mixture}

Two preliminary trials were conducted to formulate the composite flour mixtures. In the preliminary trial I, different percentages of wheat flour were substituted with locally available soya bean, mung bean and chickpea flour separately. The formulated mixtures are shown in Table 1.

Table I. Formulation of treatments of composite flour mixtures.

\begin{tabular}{lccccc}
\hline \multirow{2}{*}{ Ingredients } & \multicolumn{5}{c}{ Treatments } \\
\cline { 2 - 6 } & A1 & B1 & C1 & D1 & E1 \\
\hline Substitution of wheat flour (\%) & 30 & 40 & 50 & 60 & 70 \\
Mung bean or chickpea or soya & 105 & 140 & 175 & 210 & 245 \\
bean flour(g) & & & & & \\
Wheat flour (g) & 245 & 210 & 175 & 140 & 105 \\
Yeast (g) & 4.55 & 4.90 & 5.25 & 5.60 & 5.95 \\
Margarine (g) & 4.55 & 4.90 & 5.25 & 5.60 & 5.95 \\
Sugar (g) & 2.47 & 2.64 & 2.82 & 3.00 & 3.17 \\
Bread improver(g) & 2.47 & 2.64 & 2.82 & 3.00 & 3.17 \\
Salt (g) & 6.3 & 6.3 & 6.3 & 6.3 & 6.3 \\
Water (mL) & 210 & 210 & 210 & 210 & 210 \\
\hline
\end{tabular}

In preliminary trial II, wheat flour was completely substituted with different ratios of locally available flours. Composite flour mixtures were prepared adding different ratios of mung bean flour and chickpea flour without wheat flour. Soya bean flour was made constant (175 g) while the control treatment E2 had $100 \%$ wheat flour (Table 2). 
Table 2. Formulation of treatments without wheat flour (E2)

\begin{tabular}{lccccc}
\hline \multirow{2}{*}{\multicolumn{1}{c}{ Ingredients }} & \multicolumn{5}{c}{ Treatments } \\
\cline { 2 - 6 } & $\mathbf{A 2}$ & $\mathbf{B 2}$ & $\mathbf{C 2}$ & $\mathbf{D 2}$ & E2 \\
\hline Wheat flour (g) & 00 & 00 & 00 & 00 & 350 \\
Soya bean flour (g) & 175 & 175 & 175 & 175 & 00 \\
Mung bean flour (g) & 140 & 105 & 70 & 35 & 00 \\
Chickpea flour (g) & 35 & 70 & 105 & 140 & 00 \\
Yeast (g) & 7 & 7 & 7 & 7 & 3.5 \\
Margarine (g) & 7 & 7 & 7 & 7 & 3.5 \\
Sugar (g) & 3.5 & 3.5 & 3.5 & 3.5 & 1.75 \\
Bread Improver (g) & 3.5 & 3.5 & 3.5 & 3.5 & 1.75 \\
Salt (g) & 6.3 & 6.3 & 6.3 & 6.3 & 6.3 \\
Water (mL) & 210 & 210 & 210 & 210 & 210 \\
\hline
\end{tabular}

Sensory evaluations were conducted for the French bread manufactured using the formulations in preliminary trials I and II, using 32 untrained panellists. Based on the results of the sensory evaluation of this preliminary trial II, the $3^{\text {rd }}$ experiment was designed with different flour formulations as in Table 3. Wheat flour content (\%) in the composite flour (CF) treatments, $\mathrm{CF}(50 \%)$, $\mathrm{CF}(40 \%)$ and $\mathrm{CF}(30 \%)$ was maintained as $50 \%$ based on the composite flour mixture of soya bean flour, brown rice flour and chickpea flour. The quantities of other ingredients were adjusted based on the composite flour mixture of individual treatments except for salt and water.

Table 3. Development of composite flour (CF) mixtures with brown rice flour

\begin{tabular}{lcccc}
\hline \multirow{2}{*}{ Ingredients } & \multicolumn{4}{c}{ Treatments } \\
\cline { 2 - 5 } & CF50\%* & CF40\%* & CF30\%*) & Control \\
\hline Wheat flour (g) & $175(50 \%)$ & $210(60 \%)$ & $245(70 \%)$ & $350(100 \%)$ \\
Soya bean flour (g) & $70(20 \%)$ & $35(10 \%)$ & $35(10 \%)$ & 00 \\
Brown rice flour (g) & $70(20 \%)$ & $35(10 \%)$ & $35(10 \%)$ & 00 \\
Chickpea flour (g) & $35(10 \%)$ & $70(20 \%)$ & $35(10 \%)$ & 00 \\
Yeast (g) & 5.25 & 4.90 & 4.55 & 3.50 \\
Margarine (g) & 5.25 & 4.90 & 4.55 & 3.50 \\
Sugar (g) & 2.62 & 2.45 & 2.27 & 1.75 \\
Bread Improver (g) & 2.62 & 2.45 & 2.27 & 1.75 \\
Salt (g) & 6.3 & 6.3 & 6.3 & 6.3 \\
Water (mL) & 210 & 210 & 210 & 210 \\
\hline
\end{tabular}

* Weight \% of soya bean, brown rice and chickpea flour in composite flour mixture. 
Finally, sensory evaluation and proximate composition analysis were performed to select the best composite flour mixture.

\section{Production of French bread - straight dough method}

Flour mixtures (as per the treatments in different trials) and all the dry ingredients were mixed using a spiral mixture to form a homogeneous mixture. The French bread dough was made using a planetary mixer (Mecnosud, MX20) by kneading (18-20 minutes) while adding sufficient water. Proper gluten formation was checked by stretching a piece of dough. The dough was manually kneaded (10 -12 minutes) on a stainless steel table top and allowed for proofing (bench rest). After 1 hour of proofing raised dough was kneaded to expel the excess gas and to form a consistent dough. Then pieces of dough were moulded into characteristic elongated shape of French bread. Diagonal cuts were made on the elongated dough surface. The dough pieces were placed in oiled French bread moulds and allowed the second proofing for 1 hour. Then the moulds were placed in a preheated electric convection oven
(Blue Seal, G1100) for baking at $220 \pm 2{ }^{\circ} \mathrm{C}$ for 45-50 min.

\section{Sensory Evaluation}

Prepared French breads were evaluated for crust colour, aroma, taste, texture and overall acceptability at the sensory laboratory of the Department of Food Science and Technology, Faculty of Agriculture. Consumer oriented ranking test was conducted using 32 untrained panellists for the French bread samples manufactured using different formulations (Tables 1, 2 and 3). The best selected French bread samples were evaluated by Paired comparison test at $\mathrm{P}<0.05 \%$ confidence level (Lawless et al., 2010).

\section{Proximate composition}

Moisture (AOAC 925.10, 2000), ash (AOAC 900.2, 2012), crude protein (Kjeldahl Method, AOAC 920.176, 2012), crude fat (AOAC 2003. 06, 2012) and crude fibre (AOAC 978.10, 2012) of the final product were determined $(n=3)$ using standard methods (AOAC. 2000; AOAC. 2012: Taha, et al., 2012). Total carbohydrate content was calculated using the Formula 1 (FAO, 2003).

Formula 1.

Total carbohydrate $=[100-($ moisture + crude protein + fat + crude fibre + ash $)] \mathrm{g} / 100 \mathrm{~g}$ of food

\section{Data Analysis}

Nonparametric data from the sensory evaluation was analysed $(\mathrm{P}<0.05)$ using Friedman test, Mann Whitney U test and two tail binomial test using Minitab-14 software. The parametric data was analyzed using Minitab-14 software and Microsoft Excel (2013) for graphs.

\section{RESULTS AND DISCUSSION}

The sum of ranks values of the sensory attributes (Preliminary Trial I) of French breads prepared using 30,40, 50, 60 and $70 \%$ of mung bean, chickpea and soya bean flour formulations (A1 to E1) are shown in Tables $4 \mathrm{a}, 4 \mathrm{~b}$ and $4 \mathrm{c}$ respectively. The higher consumer preference or acceptability is shown by lower values of sum of ranks. The consumer preference decreased when the substitution of mung bean, chickpea and soya bean flour was increased (Table 4). All sensory attributes, i.e. curst colour, aroma, taste, texture and overall acceptability were not significantly different in treatment A1 $(30 \%)$ and B1(40 \%) where wheat flour was substituted with mung bean flour $(\mathrm{P}>0.05)$. The overall acceptability was significantly different at 50, 60 and $70 \%$ substitution $(\mathrm{P}<0.05)$. The crust colour and taste of French bread did not change significantly up to $50 \%$ incorporation of mung bean flour. Therefore, wheat flour can be substituted by mung bean flour up to $50 \%$ in formulation of French bread. 
Table 4. Sensory attributes of French bread prepared using the composite flour formulations

\begin{tabular}{cccccc}
\hline $\begin{array}{c}\text { Treatment } \\
\text { (\% wheat flour } \\
\text { substituted) }\end{array}$ & $\begin{array}{c}\text { Crust } \\
\text { colour }\end{array}$ & Aroma & Taste & Texture & $\begin{array}{c}\text { Overall } \\
\text { acceptability }\end{array}$ \\
\hline \multicolumn{7}{c}{ 4a. Mung bean flour } \\
\hline A1 (30\%) & $53.0 \mathrm{a}$ & $65.0 \mathrm{a}$ & $56.0 \mathrm{a}$ & $45.0 \mathrm{a}$ & $50.0 \mathrm{a}$ \\
B1 (40\%) & $64.0 \mathrm{a}$ & $63.0 \mathrm{a}$ & $67.0 \mathrm{a}$ & $55.0 \mathrm{a}$ & $54.0 \mathrm{a}$ \\
C1 (50\%) & $74.0 \mathrm{a}$ & $84.0 \mathrm{~b}$ & $77.0 \mathrm{a}$ & $94.0 \mathrm{~b}$ & $94.0 \mathrm{~b}$ \\
D1 (60\%) & $126.0 \mathrm{~b}$ & $112.0 \mathrm{c}$ & $124.0 \mathrm{~b}$ & $121.0 \mathrm{c}$ & $120.0 \mathrm{c}$ \\
E1 (70\%) & $148.0 \mathrm{c}$ & $141.0 \mathrm{~d}$ & $141.0 \mathrm{c}$ & $150.0 \mathrm{~d}$ & $147.0 \mathrm{~d}$ \\
\hline & & 4b. Chickpea flour & & \\
\hline A1 (30\%) & $51.0 \mathrm{a}$ & $48.0 \mathrm{a}$ & $50.0 \mathrm{a}$ & $53.0 \mathrm{a}$ & $53.0 \mathrm{a}$ \\
B1 (40\%) & $62.0 \mathrm{a}$ & $58.0 \mathrm{a}$ & $56.0 \mathrm{a}$ & $59.0 \mathrm{a}$ & $57.0 \mathrm{a}$ \\
C1 (50\%) & $70.0 \mathrm{a}$ & $82.0 \mathrm{~b}$ & $95.0 \mathrm{~b}$ & $73.0 \mathrm{~b}$ & $85.0 \mathrm{~b}$ \\
D1 (60\%) & $126.0 \mathrm{~b}$ & $122.0 \mathrm{c}$ & $119.0 \mathrm{c}$ & $123.0 \mathrm{c}$ & $122.0 \mathrm{c}$ \\
E1 (70\%) & $141.0 \mathrm{c}$ & $140.0 \mathrm{~d}$ & $130.0 \mathrm{~d}$ & $142.0 \mathrm{~d}$ & $133.0 \mathrm{~d}$ \\
\hline & & $4 c$. Soya bean flour & & \\
\hline A1 (30\%) & $56.0 \mathrm{a}$ & $62.0 \mathrm{a}$ & $54.0 \mathrm{a}$ & $48.0 \mathrm{a}$ & $56.0 \mathrm{a}$ \\
B1 (40\%) & $56.0 \mathrm{a}$ & $61.0 \mathrm{a}$ & $58.0 \mathrm{a}$ & $53.0 \mathrm{a}$ & $61.0 \mathrm{a}$ \\
C1 (50\%) & $74.0 \mathrm{~b}$ & $71.0 \mathrm{a}$ & $62.0 \mathrm{a}$ & $80.0 \mathrm{~b}$ & $65.0 \mathrm{a}$ \\
D1 (60\%) & $108.0 \mathrm{c}$ & $105.0 \mathrm{~b}$ & $114.0 \mathrm{~b}$ & $113.0 \mathrm{c}$ & $110.0 \mathrm{~b}$ \\
E1 (70\%) & $123.0 \mathrm{~d}$ & $121.0 \mathrm{c}$ & $132.0 \mathrm{c}$ & $126.0 \mathrm{~d}$ & $128.0 \mathrm{c}$ \\
\hline
\end{tabular}

The sum of ranks values followed by different letters within the same column is significantly different at $\mathrm{P}<0.05$

Substitution of wheat flour by chickpea flour showed similar results (Table 4 b), i.e. the crust colour was not changed significantly up to $50 \%$ substitution $(\mathrm{P}>0.05)$. Considering the overall acceptability, chickpea flour (40\%) could be mixed with $60 \%$ wheat flour without affecting all sensory attributes of French bread. The overall acceptability of soya flour substituted (30, 40 and $50 \%$ substitution) French bread was not significantly different $(P>0.05)$ with each other as shown in Table 4c. Thus, up to $50 \%$ substitution of soya bean flour would be acceptable in French bread formulation.
For further development, French bread was prepared using composite flour mixtures which were reformulated in Trial II as shown in Table 2. The sum of ranks values of the sensory attributes of French bread prepared using these formulations are shown in Table 5. Mung bean flour in composite mixtures of treatment A2, B2, C2 and D2 were 140g, 105g, 70g and 35g respectively. All sensory attributes of French bread prepared by treatments A2, B2, C2 and D2 were significantly different $(\mathrm{P}<0.05)$ in comparison to E2 (control). Soya bean flour (\%) in treatments (A2, B2, C2 and D2) was constant. Higher sum of square values, 141 (A2) and 116 (B2) were recorded by $40 \%$ (140 g) and $30 \%$ (105 g) mung bean flour 
added composite mixtures due to unpleasant taste and aroma of mung bean flour. However, aroma, taste, texture and overall acceptability were not significantly different $(\mathrm{P}>0.05)$ between $\mathrm{C} 2$ and $\mathrm{D} 2$. Therefore, complete substitution (100\%) of composite mixture of soya bean, mung bean and chickpea flour instead of wheat flour was unsuccessful. French breads developed by these formulations were unacceptable by the panellists due to mung bean taste and aroma. Therefore, mung bean flour was replaced by brown rice flour in reformulation of composite flour mixtures for further development.

Table 5. Sensory attributes of French bread developed by composite flour mixtures of mung bean, chickpea and soya bean flours.

\begin{tabular}{cccccc}
\hline & \multicolumn{5}{c}{ Sum of Ranks } \\
\cline { 2 - 6 } Formulation & Crust colour & Aroma & Taste & Texture & $\begin{array}{c}\text { Overall } \\
\text { acceptability }\end{array}$ \\
\hline A 2 & $134.0 .0 \mathrm{a}$ & $127.0 \mathrm{a}$ & $132.0 \mathrm{a}$ & $142.0 \mathrm{a}$ & $141.0 \mathrm{a}$ \\
B 2 & $117.0 \mathrm{~b}$ & $90.0 \mathrm{~b}$ & $121.0 \mathrm{~b}$ & $125.0 \mathrm{~b}$ & $116.0 \mathrm{~b}$ \\
C 2 & $72.0 \mathrm{c}$ & $109.0 \mathrm{c}$ & $78.0 \mathrm{c}$ & $86.0 \mathrm{c}$ & $96.0 \mathrm{c}$ \\
D 2 & $98.0 \mathrm{~d}$ & $101.0 \mathrm{c}$ & $82.0 \mathrm{c}$ & $95.0 \mathrm{c}$ & $89.0 \mathrm{c}$ \\
E 2 & $59.0 \mathrm{e}$ & $53.0 \mathrm{~d}$ & $67.0 \mathrm{~d}$ & $32.0 \mathrm{~d}$ & $38.0 \mathrm{~d}$ \\
\hline
\end{tabular}

The sums of ranks values followed by different letters within the same column are significantly different at $\mathrm{P}<0.05$.

In the final experiment, French bread was prepared using the reformulated flour mixtures and ingredients as given in Table 3. Substitution of $30 \%$ composite flour (CF30\%: 10\% soya bean flour, $10 \%$ brown rice flour, $10 \%$ chickpea flour) and $40 \%$ composite flour (CF40\%: 10\% soya bean flour, $10 \%$ brown rice flour, $20 \%$ chickpea flour) for wheat flour was the most acceptable composite flour mixtures for French breads (Figure 1). Substitution of composite flours, $\mathrm{CF} 30 \%$ and $\mathrm{CF} 40 \%$ was successfully used in French bread making without affecting the crust colour, aroma and taste compared to the control. Crust colour is formed due to caramelization and Maillard reaction, in which protein and sugar in flours react with each other during the baking process (Dhingra and Jood, 2002).

Loaf volume and crumb structure (the pattern and size of holes inside the loaf) of French bread are mainly determined by protein content and quality (Baardseth et al., 2000). Mixing of defatted soya flour is desirable for the development of crumb structure (Bhatt and Gupta, 2015). Therefore, the selected CF30\% and CF40\% flour mixtures with $10 \%$ soya bean flour as compatible with the above findings. A highly porous, glutinous and collapsible or shrinkable crumb is formed after baking with formulation of wheat flour of waxy starch. Thus crumb of French bread is affected by the type and quality of wheat flour (Baik et al., 2003).

Texture and overall acceptability of French bread prepared using CF30\% and CF40\% were significantly different $(\mathrm{P}<0.05)$ with each other. French bread samples (CF30\% and $\mathrm{CF} 40 \%$ ) were further subjected to the paired comparison test using 32 untrained panellists. The results showed that the crust colour, aroma, taste, texture and overall acceptability were not significantly different $(P>0.05)$ between French bread samples prepared by composite flour mixtures of 
CF30\% and CF40\%. Therefore, both composite flour mixtures are able to substitute 30-40 \% wheat flour successfully in French bread production.

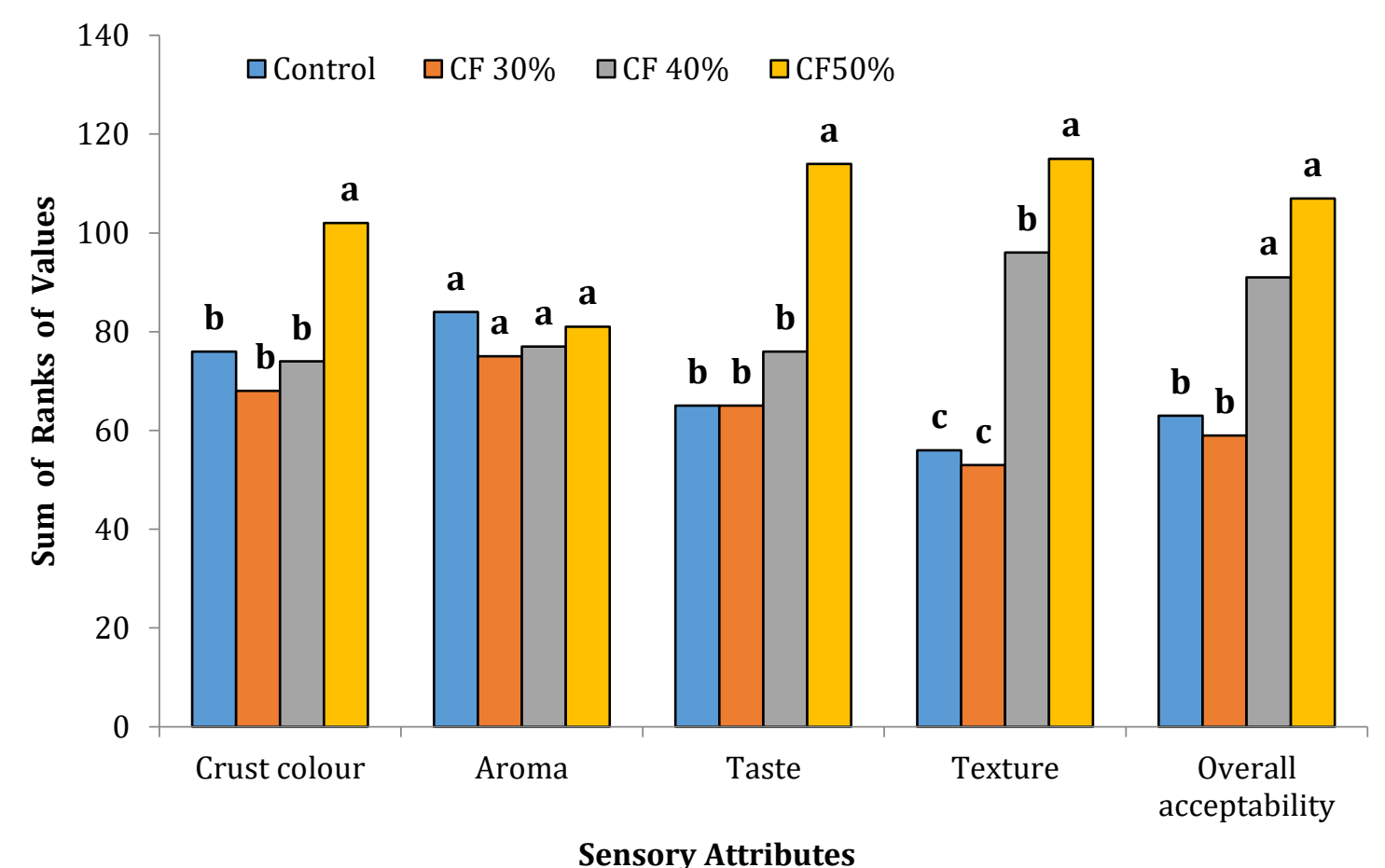

\section{Figure 1. Sum of ranks values of sensory attributes of French bread prepared using different formulations}

CF30\% (10\% soya bean flour: 10\% brown rice flour: 10\% chickpea flour), CF40 \% (10\% soya bean flour: $10 \%$ brown rice flour: $20 \%$ chickpea flour), CF50\% (20\% soya bean flour: $20 \%$ brown rice flour: $10 \%$ chickpea flour), Control ( $100 \%$ wheat flour)

The sum of ranks values followed by different letters within the same sensory attribute are significantly different at $\mathrm{P}<0.05$.

\section{Proximate composition of French bread samples}

Proximate composition of French breads (CF30\% and CF40\% compared with the control) is presented in Table 6. Moisture content of bread samples significantly decreased $\quad(\mathrm{P}<0.05)$ with increasing percentage of composite flour mixture (soya bean, chickpea and brown rice) from $30 \%$ to $40 \%$. Moisture in the control sample was $33.17 \%$ (wet basis, wb), while in CF30\% and CF $40 \%$, values were 30.33 and $29.47 \%(w b)$. Lower moisture content in French bread of the composite flour formulation $\mathrm{CF} 40 \%$ and CF30\% was due to lower content of wheat flour than in the control samples. Low moisture content provides an additional benefit by extending the shelf life. 
Table 6. Proximate composition of French bread samples

\begin{tabular}{lccc}
\hline & \multicolumn{3}{c}{ Formulation } \\
\cline { 2 - 4 } \multicolumn{1}{c}{ Constituents (\%) } & A (Control) & CF30\% & CF40\% \\
\hline Moisture & $33.17 \pm 0.05 \mathrm{a}$ & $30.33 \pm 0.13 \mathrm{~b}$ & $29.47 \pm 0.03 \mathrm{c}$ \\
Protein & $12.87 \pm 0.01 \mathrm{a}$ & $14.03 \pm 0.01 \mathrm{~b}$ & $14.80 \pm 0.02 \mathrm{~b}$ \\
Fat & $2.43 \pm 0.06 \mathrm{a}$ & $4.99 \pm 0.06 \mathrm{~b}$ & $5.39 \pm 0.01 \mathrm{c}$ \\
Fibre & $0.87 \pm 0.12 \mathrm{a}$ & $1.3 \pm 0.01 \mathrm{~b}$ & $1.57 \pm 0.04 \mathrm{c}$ \\
Ash & $1.41 \pm .01 \mathrm{a}$ & $1.8 \pm 0.02 \mathrm{~b}$ & $2.09 \pm 0.01 \mathrm{c}$ \\
Carbohydrate* & 49.25 & 47.45 & 46.68 \\
\hline
\end{tabular}

The values followed by different letters within the same column are significantly different at $\mathrm{P}<0.05$. [Values: Mean $\pm \operatorname{SD}(\mathrm{n}=3),{ }^{*}$ Obtained from subtraction method]

A: Control (100\% wheat flour), B: $30 \%$ composite flour (10\% soya bean, $10 \%$ brown rice, $10 \%$ chickpea), C: $40 \%$ composite flour (10\% soya bean, $10 \%$ brown rice, $20 \%$ chickpea)

The protein content in French bread prepared using composite formulations CF30\% (14.0\% wb) and CF40\% (14.8\% wb) was significantly $(\mathrm{P}<0.05)$ higher than in the control (12.9\%). Wheat flour was replaced by $10 \%$ soya bean flour in CF30\% and CF $40 \%$ composite flours. High protein content in soya bean flour is responsible for the high protein content in French bread. The fat content (4.99-5.39\%) in the French bread was also significantly higher $(\mathrm{P}<0.05)$ than in the control (2.43\%) due to incorporation of soya bean flour in the formulation which has a high fat content.

The fat, fibre and ash contents of the developed French bread too, increased while the carbohydrate content decreased, with increasing levels of soya bean, chickpea and brown rice flours. Similarly, higher mineral and fibre contents were obtained in composite flour added bread samples than in the control. The contents were significantly different between bread prepared using CF30\% and CF40\% $(\mathrm{P}<0.05)$. These compositional differences in bread are due to the addition of brown rice, soya and chickpea flour and their compositional variations.
Substitution of wheat flour by composite flour mixtures increased the nutritional value of the French bread substantially. The French bread prepared using 40\% composite flour increased the constituents as follows: protein $14 \%$, Fat $121 \%$, fibre $80 \%$, ash $48 \%$. These values were higher in French breads substituted with 30\% composite flour (protein 9.1\%, fat 105.3\%, fibre $55.2 \%$ and ash $31.2 \%$ ). Moisture content in French bread increased with increasing percentage of composite flour mixture. French bread prepared with composite flour (CF40\%) had higher moisture content $(11.2 \%)$ than in French bread prepared with CF30\% composite flour (8.6\%). Similarly, the carbohydrates reduced by $5.22 \%$ in French bread prepared using CF40\%, which was higher than in French bread prepared using CF 30\% composite flour $(3.47 \%)$.

The shelf-life of French bread may also increase with the flour formulations used in the present study, since these flours contain low amylose content (Sasaki, et al., 2000). Starches with low amylose are more resistant to retrogradation during storage (Hayakawa, et al., 1997). Thus, composite mixtures of this nature with other locally 
grown cereal flours warrants further investigation.

\section{CONCLUSION}

Two composite flour mixtures, 30\% $(10 \%$ soya bean flour, $10 \%$ brown rice flour, $10 \%$ chickpea) and 40\% (10\% soya bean flour, $10 \%$ brown rice flour, $20 \%$ chickpea flour) were successfully used for substitution of wheat flour in French bread production. The sensory attributes of the developed French breads were similarly acceptable as French

\section{REFERENCES}

AOAC (2000). Official Methods of Analysis. Association of Official Analytical Chemists. $13^{\text {th }}$ Edition. Washington D.C., USA.

AOAC (2012). Official methods of analysis. Association of official analytical chemists. 19th Edition, Washington D.C., USA.

Baardseth, P., Kvaal, K., Lea, P., Ellekjær, M.R. and Færgestad, E.M. (2000). The effects of bread making process and wheat quality on French baguettes. Journal of Cereal Science. 32, 73-87. doi:10.1006/jcrs.2000.0320.

Baik, B.K., Park, C.S., Paszczynska, B. and Konzak, C.F. (2003) Characteristics of noodles and bread prepared from double-null partial waxy wheat. Cereal Chemistry. 80(5), 627-633. doi:10.1094/CCHEM.2003.80.5.627.

Bhatt, S.M. and Gupta, R.K. (2015) Bread (composite flour) formulation and study of its nutritive, phytochemical and functional properties. Journal of Pharmacognosy and Phytochemistry. 4(2), 254-268. http://www.phyto journal.com/archives/2015/vol4issu e2/PartD/4-3-18.1-664.pdf

Bibiana, I., Grace, N. and Julius, A. (2014) Quality Evaluation of Composite Bread bread made with $100 \%$ wheat flour, to the panellists. There was no significant difference $(\mathrm{P}>0.05)$ in the crust colour, aroma, taste, texture and overall acceptability of developed French bread using the composite flour mixtures $30 \%$ and $40 \%$. Therefore, partial substitution of wheat flour by locally available soya bean, brown rice and chickpea flour increased the protein, fat, fibre and ash content in French bread. These findings are valuable for the bakery industry, nutritionists, food regulators and the consumers.

Produced from Wheat, Maize and Orange Fleshed Sweet Potato Flours. American Journal of Food Science and Technology. 2(4), 109-115. doi:10.12691/ajfst-2-4-1.

Comino, I., Moreno, Mde L, Real A, RodríguezHerrera A. and Barro, F. (2013). Sousa C. The gluten-free diet: testing alternative cereals tolerated by celiac patients. Nutrients. 5(10), 4250-4268. Published 2013 Oct 23. doi:10.3390/nu5104250

Devi, P.B., Vijayabharathi, R. and Sathyabama, S. (2014). Health benefits of finger millet (Eleusine coracana L.) polyphenols and dietary fiber: a review. Journal Food Science and Technology. 51, 1021-1040. https://doi.org/10.1007/s13197011-0584-9

Dewettinck, K., Van Bockstaele, F., Kühne, B., Van de Walle, D., Courtens, T.M. and Gellynck, X. (2008). Nutritional value of bread: Influence of processing, food interaction and consumer perception. Journal of Cereal Science. 48, 243-257. doi:10.1016/j.jcs.2008.01.003.

Dhingra, S. and Jood, S. (2002). Organoleptic and nutritional evaluation of wheat breads supplemented with soybean and barley flour. Food Chemistry. 77, 479-488. doi:10.1016/S0308-8146 
(01)00387-9.

Dooshima, I.B. (2014). Quality Evaluation of Composite Bread Produced from Wheat, Defatted Soy and Banana Flours. International Journal of Nutrition and Food Sciences. 3(5), 471-476. doi:10.11648/j.ijnfs.20140305.26.

Eddy N.O, Udofia P.G. and Eyo D. (2007). Sensory evaluation of wheat/cassava composite bread and effect of label information on acceptance and preference. African Journal of Biotechnology. 6 (20), 2415-2418.

Færgestad, E.M., Molteberg, E.L. and Magnus, E.M. (2000) Interrelationships of protein composition, protein level, baking process and the characteristics of hearth bread and pan bread. Journal of Cereal Science. 31, 309-320. doi:10.1006/jcrs.1999.0304.

Food and Agriculture Organization (FAO) (2003). Food energy - methods of analysis and conversion factors, Report of a Technical Workshop, Rome, 3-6 December 2002, FAO Food and Nutrition paper. 77, Chapter 2. pp 64. ISBN 92-5-105014-7

Hayakawa, K., Tanaka, K., Nakamura, T., Endo, S. and Hoshino, T. (1997). Quality characteristics of waxy hexaploid wheat (Triticum aestivum L.): Properties of starch gelatinization and retrogradation. Cereal Chemistry. 74, 576-580.

Hugo L.F., Rooney L.W. and Taylor J.R.N. (2000). Malted sorghum as a functional ingredient in composite bread, Cereal Chemistry. 77, 428-432.

Kadan, R.S., Robinson, M.G., Thibodeaux, D.P. and Pepperman, A.B. (2001). Texture and other physicochemical properties of whole rice bread. Journal of Food Science. doi:10.1111/j.13652621.2001.tb08216.x.
Lawless, H.T. and Heymann, H. (2010). Discrimination Testing. Sensory Evaluation of Food: Principles and Practices. 2, 79-99.

Mepba, H.D., Eboh L. and Nwaojigwa S.U. (2007). Chemical composition, functional and baking properties of wheat-plantain composite flours. African Journal of Food, Agriculture, Nutrition and Development. 7(1). doi:10.4314/ajfand.v7i1.

Noomhorm, A., Bandola, D.C. and Kongseree, N. (1994). Effect of rice variety, rice flour concentration and enzyme levels on composite bread quality. Journal of the Science of Food and Agriculture. 64, 433-440. doi:10.1002/jsfa. 2740640407.

Olaoye, O.A., Onilude, A.A., and Idowu, O.A. (2006). Quality characteristics of bread produced from composite flours of wheat, plantain and soybeans. African Journal of Biotechnology. doi:10.5897/AJB06.014.

Rosales-Juárez, M., González-Mendoza, B., López-Guel, E.C., Lozano-Bautista, F., Chanona-Pérez, J., Gutiérrez-López, G., Farrera-Rebollo, R. and CalderónDomínguez, G. (2008). Changes on dough rheological characteristics and bread quality as a result of the addition of germinatedand non-germinated soybean flour. Food and Bioprocess Technology. 1, 152-160. doi:10.1007/ s11947-007-0004-3.

Sabanis, D. and Tzia C. (2009). Effect of Rice, Corn and Soy Flour Addition on Characteristics of Bread Produced from Different Wheat Cultivars. Food and Bioprocess Technology. 2(1), 6879. doi: $10.1007 / \mathrm{s} 11947-007-0037-7$.

Sasaki, T., Yasui, T. and Matsuki, J. (2000). Effect of amylose content on gelatinization, retrogradation, and pasting properties of starches from waxy and nonwaxy wheat and their F1 
seeds. Cereal Chemistry. 77:58-63. Seib, P. A. 2000. Reduced-amylose wheats and Asian noodles. Cereal Foods World. 45, 504-512.

Shewry, P.R., Halford, N.G, Belton, P.S. and Tatham A.S. (2002). The structure and properties of gluten an elastic protein from wheat grain. Philosophical Transactions of the Royal Society B: Biological Sciences. 357(1418), 133142. doi:10.1098/rstb.2001.1024

Shewry, P.R. and Hey, S.J. (2016). Do we need to worry about eating wheat? Nutrition Bulletin. 41(1), 6-13. doi: 10.1111/nbu.12186

Taha, A.Y., Metherel, A.H. and Stark, K.D. (2012). Comparative analysis of standardised and common modifications of methods for lipid extraction for the determination of fatty acids. Food Chemistry. doi:10.1016/j.foodchem.2012.02.087.

Tweed, A.R. (1983). A look at French "Baguettes". Cereal Foods World. 28, 397-399.

Wickramarathna, G.L. and Arampath, P.C. (2003) Utilization of Okara in Bread Making. Ceylon Journal of Science, Biological Sciences. (31), 29-33. https://pdfs.semanticscholar.org/127 9/9320dadbdfe53281efd2c9dfc2976 3f0e47b.pdf. 